\title{
Pengaruh Perlakuan Sexing terhadap Konsumsi Pakan, Pertambahan Berat Badan, dan Konversi Pakan Ayam Ras Pedaging di Kandang Semi Closed House
}

\section{Effect of Sexing Treatment on Feed Intake, Average Daily Gain, and Feed Conversion Ratio of Broiler in Semi Closed House}

\author{
Herry Susanto ${ }^{1}$, Herawati $M^{1}$, Rastosari $A^{1}$ \\ ${ }^{\text {I}}$ Fakultas Peternakan, Universitas Tulang Bawang Lampung, Jl. Gajah Mada, Bandar \\ Lampung \\ Herrysusanto13881@gmail.com
}

\begin{abstract}
The purpose of this study was to test and evaluate feed intake, average daily gain and feed conversion ratio of male and female broilers with a separate maintenance treatment (sexing) in semi-closed house cages. The study was conducted at Joni Farm, Tegineneng Subdistrict, Pesawaran District. The type of research used was experimental research comparing the performance of male and female broilers that were kept separately (sexing) at the age of 12 days to 30 days. Experimental broilers used during research were 94 male and 94 female Lohmann. The variables observed in this study were male and female broiler on feed intake, average daily gain (ADG) and Feed Convertion Ratio (FCR). Based on the results of statistical analysis showed sexing has a significant effect on ADG and FCR. Sexing had no effect on feed intake. The average feed intake of male broiler chicken feed was 128.12 grams, while the consumption of female broiler was 120.00 grams. Average daily gain (ADG) of male broiler was higher than female broiler, ADG male broiler were 75.61 grams, while ADG female broiler were 66.28 grams. FCR of female broilers was 1.77 wich higher than male broilers was 1.57 .
\end{abstract}

Keywords: Average Daily Gain, Feed Convertion, Feed Intake, Sexing Chicken Broiler

\section{PENDAHULUAN}

Sektor peternakan mempunyai peran yang sangat penting dalam memenuhi kebutuhan gizi masyarakat. Sumber daya manusia yang berkualitas ditentukan oleh pendidikan yang tepat guna dan pemenuhan gizi masyarakat. Pemenuhan gizi masyarakat sebagian besar berasal dari protein hewani. Protein hewani yang banyak digemari masyarakat dan memiliki kandungan protein tinggi adalah daging ayam. Daging ayam yang banyak dikonsumsi masyarakat sampai saat ini adalah daging ayam broiler dan ayam kampung.

Ayam broiler adalah ayam tipe pedaging yang dihasilkan dari hasil seleksi sistematis sehingga dapat tumbuh dan mencapai bobot badan tertentu dalam waktu relatif singkat. Tipe pedaging yang dimaksud adalah ayam yang dipelihara dengan tujuan untuk dipanen dan diambil dagingnya (bukan telurnya) sebagai sumber protein hewani bagi konsumen (Muwarni, 2010).

Ayam broiler merupakan ternak yang paling ekonomis bila dibandingkan dengan ternak lain, kelebihan yang dimiliki adalah kecepatan pertambahan/produksi daging dalam waktu yang relatif cepat dan singkat atau 
sekitar 4 sampai 5 minggu produksi daging sudah dapat dipasarkan atau dikonsumsi. Keunggulan ayam broiler antara lain pertumbuhannya yang sangat cepat dengan bobot badan yang tinggi dalam waktu yang relatif pendek, konversi pakan kecil, menghasilkan kualitas daging berserat lunak, timbunan daging baik dan dada lebih lebar (North and Bell,1990).

Berdasarkan pedoman pemeliharaan Lohman Broder MB 202 PT. Japfa Comfeed Indonesia 2008, terdapat perbedaan konsumsi pakan, pertambahan berat badan dan konversi pakan antara broiler Jantan dan betina. Data perbedaan tersebut kami sajikan pada Tabel 1 dan 2 di bawah ini.

Tabel 1. Data Performa Lohmann meat broiler Jantan kandang close

\begin{tabular}{crrrr}
\hline $\begin{array}{c}\text { Umur } \\
\text { (minggu) }\end{array}$ & $\begin{array}{r}\text { Berat badan } \\
(\mathrm{g})\end{array}$ & $\begin{array}{c}\text { Pertambahan } \\
\text { BB }(\mathrm{g})\end{array}$ & $\begin{array}{c}\text { Konsumsi } \\
\text { ransum }(\mathrm{g})\end{array}$ & $\begin{array}{c}\text { Konversi } \\
\text { ransum }(\mathrm{g})\end{array}$ \\
\hline 0 & 42 & & & \\
1 & 184 & 20,29 & 162 & 0,879 \\
2 & 477 & 41,86 & 379 & 1,132 \\
3 & 943 & 66,57 & 514 & 1,291 \\
4 & 1.550 & 86,71 & 1.170 & 1,435 \\
\hline
\end{tabular}

Sumber : Pedoman Pemeliharaan Lohmann Broiler MB 202 PT Japfa Comfeed Indonesia, 2008

Tabel 2. Data Performa Lohmann meat broiler Betina kandang close

\begin{tabular}{crrrr}
\hline $\begin{array}{c}\text { Umur } \\
\text { (minggu })\end{array}$ & $\begin{array}{r}\text { Berat badan } \\
(\mathrm{g})\end{array}$ & $\begin{array}{c}\text { Pertambahan } \\
\text { BB }(\mathrm{g})\end{array}$ & $\begin{array}{c}\text { Konsumsi } \\
\text { ransum }(\mathrm{g})\end{array}$ & $\begin{array}{c}\text { Konversi } \\
\text { ransum }(\mathrm{g})\end{array}$ \\
\hline 0 & 42 & & & \\
1 & 183 & 20,14 & 169 & 0,924 \\
2 & 463 & 40,00 & 359 & 1,140 \\
3 & 882 & 59,86 & 615 & 1,295 \\
4 & 1.403 & 74,43 & 887 & 1,447 \\
\hline
\end{tabular}

Sumber : Pedoman Pemeliharaan Lohmann Broiler MB 202 PT Japfa Comfeed Indonesia, 2008

Tujuan penelitian ini adalah untuk mengetahui pengaruh perlakuan sexing terhadap perbedaan konsumsi pakan, pertambahan berat badan dan konversi pakan.

\section{METODE PENELITIAN}

\section{Metode Penelitian}

Metode penelitian yang digunakan adalah metode eksperimen (experimental reasearch) yaitu meneliti pengaruh perlakuan terhadap perilaku 
yang timbul sebagai akibat perlakuan yang diberikan secara sengaja oleh peneliti (Alsa, 2004). Penelitian yang dilakukan adalah membandingkan kinerja ayam ras pedaging (broiler) jantan dan betina yang dipelihara secara terpisah (sexing) pada usia 12 hari sampai 30 hari pemeliharaan terhadap pertambahan berat badan dan konversi pakan. Peubah yang akan diamati dalam penelitian ini adalah pertambahan berat badan harian $(\mathrm{PBBH})$ dan konversi pakan atau Feed Conversion Ratio (FCR).

Metode pemisahan ayam broiler jantan dan betina dilaksanakan pada usia 12 hari dengan cara mengambil dan mengelompokkan ayam broiler berdasarkan jenis kelaminnya. Dilakukan pada usia 12 hari karena secara fisik ayam broiler jantan dan betina mulai nampak perbedaannya.

\section{Tempat dan Waktu Penelitian}

Penelitian dilaksanakan di Farm Joni Desa Gedung Gumanti, Kecamatan Tegineneng, kabupaten Pesawaran Lampung selama 20 hari. Dipilihnya Farm Joni sebagai tempat penelitian karena ada beberapa kandang di Farm Joni yang sudah di upgrade ke kandang semi closed house. Total populasi di dalam satu lokasi Farm Joni 170.000 ekor, adapun kapasitas kandang untuk tempat penelitian 8.500 ekor.

\section{Cara Pengumpulan Data}

Teknik pengumpulan data yang dipakai dengan cara pengumpulan data kuantitatif dengan menggunakan lembar observasi untuk mendapatkan data konsumsi pakan, $\mathrm{PBBH}$, dan konversi pakan.

\section{Analisa Data}

Analisa data $\mathrm{PBBH}$ dan konversi pakan yang digunakan adalah Independent sample t-test dengan menggunakan program SPSS Versi 16. Sedangkan analisa konsumsi pakan menggunakan data perbandingan antara broiler jantan dan betina. Adapun kriteria pengambilan keputusannya adalah

1. Apabila nilai probabilitas $(p) \leq 0,05$, maka terdapat pengaruh sexing yang signifikan terhadap PBBH dan konversi pakan atau Feed Conversi Ratio (FCR) ayam ras pedaging

2. Apabila nilai probabilitas $(p)>0,05$, maka terdapat pengaruh sexing yang tidak signifikan terhadap PBBH, dan konversi pakan atau Feed Conversi Ratio (FCR) ayam ras pedaging

\section{Materi Penelitian}

\section{A. Alat}

Peralatan yang digunakan pada penelitian ini adalah Kandang semi closed house (terlampir), Baby chick feeder (BCF), tempat minum manual 1 galon, gas brooder atau pemanas berupa gasolex, termometer ruang, tempat minum otomatis, skat bambu dan kawat, hanging feeder atau tempat pakan gantung kuning $5 \mathrm{~kg}$, timbangan digital $5 \mathrm{~kg}$, timbangan gantung digital $20 \mathrm{~kg}$ untuk penimbangan akhir minggu, timbangan kapasitas $50 \mathrm{~kg}$ merk salter, lampu LED 5 watt, Hand spray, ember sebanyak 2 buah dan bak hitam 1 buah, tirai plastik untuk masa brooding, Exhaust fan 50", alat tulis untuk pencatatan rekording dapat dilihat pada Lampiran 17, 18 dan 19 Halaman 52, 53 dan 53. 


\section{B. Bahan}

\section{a. Ayam}

Bahan yang digunakan adalah ayam ras pedaging dengan strain Lohmann dengan merk dagang MB 202, kelompok 1 sebanyak 94 ekor dan kelompok 2 sebanyak 94 ekor (Lampiran 20 Gambar 28 dan 29).

\section{b. Pakan}

Pakan yang digunakan digunakan dalam penelitian ini tiga jenis yaitu fine crumble, crumble dan pellet dengan merk dagang SB 10, SB 11 dan SB 12 (Lampiran 20 Gambar 30) produksi PT. Japfa Comfeed Indonesia, Tbk. Fine crumble (SB10) digunakan di umur 1 hari sampai 10 hari sebanyak $400 \mathrm{~g} / \mathrm{ekor}$, crumble (SB11) digunakan dari umur 11 sampai 21 hari sebanyak 900 g/ekor dan pellet (SB 12) digunakan dari umur 22 sampai dengan panen. Kandungan nutrisi dari jenis-jenis pakan yang digunakan dapat dilihat pada tabel 3 , tabel 4 dan tabel 5 .

Tabel 3. Kandungan Nutrisi Pakan

\begin{tabular}{lcccc}
\hline \multicolumn{1}{c}{\begin{tabular}{c} 
Jenis \\
kandungan \\
\multicolumn{1}{c}{ nutrisi }
\end{tabular}} & Batas & & Jumlah (\%) \\
& & SB 10 & 11 & SB 12 \\
\hline Air & Maks & 12 & 12 & 12 \\
Protein kasar & Min & 22 & 21 & 19 \\
Lemak kasar & Min & 5 & 5 & 5 \\
Serat kasar & Maks & 4 & 5 & 5 \\
Abu & Maks & 7 & 7 & 7 \\
Kalsium & Min & 0,65 & 0,5 & 0,55 \\
Phospor & Min & 0,5 & 0,5 & 0,45 \\
Enzym & + & & & \\
\hline
\end{tabular}

\section{c. Air minum}

Air minum yang digunakan berasal dari air sumur bor yang sudah melalui proses penyaringan dan penampungan yang diberikan secara ad libitum.

\section{HASIL DAN PEMBAHASAN}

\section{Pengaruh Perlakuan Terhadap Konsumsi Pakan}

Jumlah dan rata-rata konsumsi pakan ayam ras pedaging pada perlakuan sexing (jantan dan betina) berbeda yang diperoleh selama penelitian dapat dilihat pada Tabel 8 dan Gambar 1. 
Tabel 4. Jumlah dan rata-rata konsumsi pakan (g/ekor/hari) ayam broiler pada perlakuan sexing (jantan dan betina) yang berbeda

\begin{tabular}{|c|c|c|}
\hline \multirow[b]{2}{*}{ Umur (Hari) } & \multicolumn{2}{|c|}{ Konsumsi (gr) } \\
\hline & Jantan & Betina \\
\hline 12 & 66 & 63 \\
\hline 13 & 76 & 78 \\
\hline 14 & 90 & 83 \\
\hline 15 & 92 & 88 \\
\hline 16 & 95 & 93 \\
\hline 17 & 104 & 107 \\
\hline 18 & 112 & 103 \\
\hline 19 & 118 & 113 \\
\hline 20 & 126 & 123 \\
\hline 21 & 137 & 133 \\
\hline 22 & 154 & 143 \\
\hline 23 & 162 & 143 \\
\hline 24 & 162 & 148 \\
\hline 25 & 166 & 153 \\
\hline 26 & 171 & 153 \\
\hline 27 & 172 & 153 \\
\hline 28 & 175 & 163 \\
\hline Jumlah & 2.178 & 2.040 \\
\hline Rata-rata & 128,12 & 120,00 \\
\hline Standar Deviasi & 36,93 & 31,40 \\
\hline
\end{tabular}

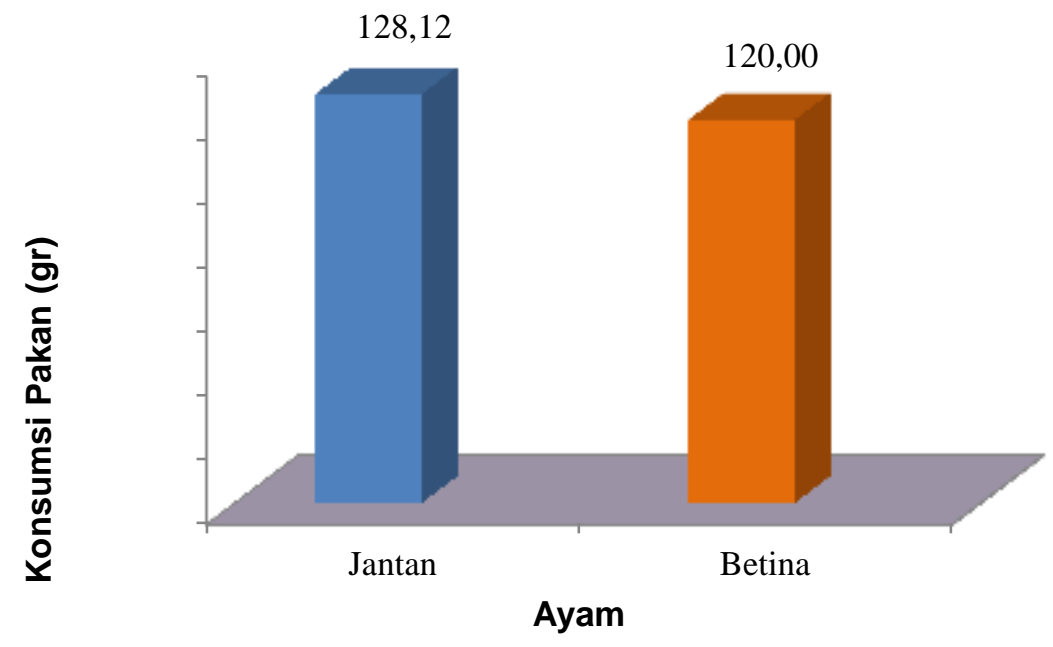

Gambar 1. Rata-rata konsumsi pakan ayam broiler pada perlakuan (jantan dan betina) yang berbeda. 
Hasil penelitian menujukkan konsumsi pakan ayam ras pedaging jantan $128,12 \pm 36,93$ gram dan ayam ras pedaging betina 120,00 $\pm 31,40$ gram. Konsumsi pakan ayam ras pedaging jantan lebih tinggi 8,12 gram dibandingkan dengan betina. Hal ini sesuai dengan hasil penelitian Ermawati, et al (2011), yang menyatakan bahwa konsumsi pakan ayam ras pedaging jantan lebih banyak dibandingkan dengan ayam ras pedaging betina $(93,78$ gram vs 84,29 gram) yang dipelihara pada kandang tertutup selama 33 hari. Menurut National Research Council (1994), konsumsi pakan dipengaruhi oleh bentuk dan kualitas pakan, kecepatan pertumbuhan, kesehatan ternak dan suhu lingkungan.

\section{Pengaruh Perlakuan terhadap Pertambahan Bobot Badan Harian (PBBH)}

Berdasarkan hasil analisis diperoleh rata-rata Pertambahan Bobot Badan Harian ayam ras pedaging jantan dan betina disajikan pada Tabel 9 dan Gambar 2.

Tabel 5. Rata-rata bobot badan dan PBBH ayam ras pedaging jantan dan betina

\begin{tabular}{crrr}
\hline \multirow{2}{*}{ No } & Umur (Hari) & \multicolumn{2}{c}{ PBBH (gr) } \\
\cline { 3 - 4 } & & \multicolumn{1}{c}{ Jantan } & Betina \\
\hline 1 & 12 & - & - \\
2 & 14 & $67,66 \pm 5,20$ & $64,60 \pm 4,97$ \\
3 & 21 & $77,52 \pm 7,75$ & $66,47 \pm 6,65$ \\
4 & 28 & $81,65 \pm 4,80$ & $67,77 \pm 3,99$ \\
\hline Jumlah & & 226,83 & 198,84 \\
\hline Rata-rata & & 75,61 & 66,28 \\
\hline
\end{tabular}

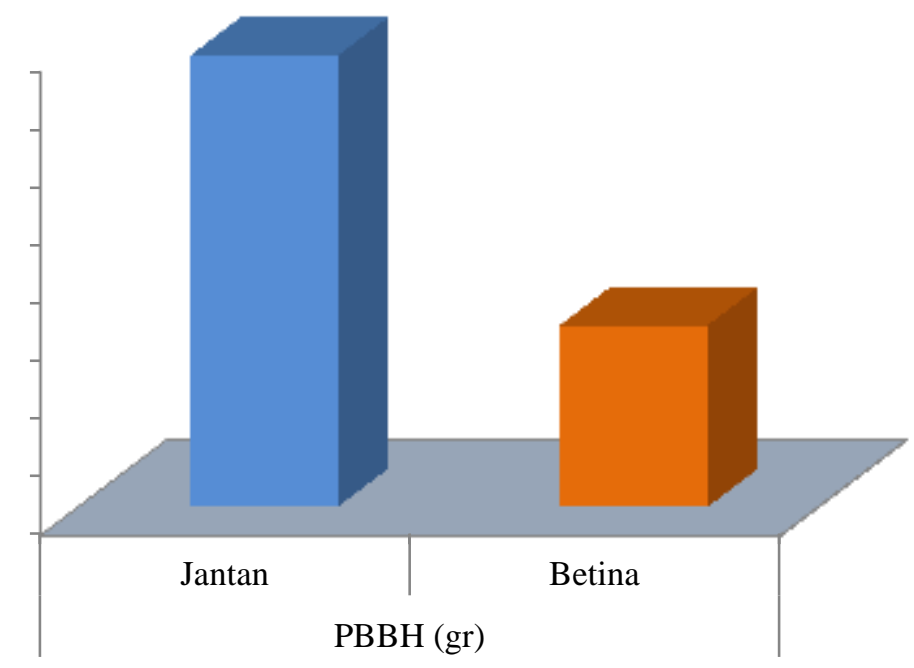

Gambar 2. Rata-rata PBBH ayam jantan dan betina

Hasil analisis t-test menunjukkan bahwa perlakuan sexing ayam ras pedaging berpengaruh nyata $(p<0,05)$ terhadap pertambahan bobot badan 
harian $(\mathrm{PBBH})$. Adanya pengaruh ini terlihat adanya perbedaan $\mathrm{PBBH}$ antara ayam ras pedaging jantan dan betina. $\mathrm{PBBH}$ ayam ras pedaging jantan yaitu 75,61 gram lebih tinggi dibandingkan dengan ayam ras pedaging betina yaitu 66,28 gram selama 17 hari pemeliharaan. Adanya perbedaan yang signifikan ini lebih disebabkan oleh ayam ras pedaging jantan lebih aktif makan sehingga pertambahan bobot badan lebih tinggi.

Hal ini sesuai dengan hasil penelitian Ermawati, et al. (2011), pemeliharaan di kandang semi close house selama 33 hari dimana bobot badan akhir pemeliharaan yang jantan 1.927,04 dengan PBBH 57,12 gram dan bobot akhir pemeliharaan betina 1.730,33 dengan PBBH 51,16 gram. Diperkuat lagi dengan hasil penelitian Wardhani dan Setiarini (2010), ayam ras pedaging baik jantan maupun betina saat berumur 19 atau 20 hari terjadi laju pertumbuhan paling pesat dan mencapai puncaknya dimana pada saat itu berat badan adalah 806,96 gram untuk ayam ras pedaging betina dan 939,63 gram untuk ayam ras pedaging jantan dengan PBBH 132,67 gram.

\section{Pengaruh Perlakuan Sexing terhadap Konversi Pakan}

Data konversi pakan (Feed Conversi Ratio) hasil penelitian pada ayam ras pedaging jantan dan betina dari perlakuan sexing tersaji pada Tabel 6 dan Gambar 3.

Tabel 6. Rata-rata konversi pakan ayam broiler jantan dan betina

\begin{tabular}{cc}
\hline Ayam & FCR \\
\hline Jantan & 1,57 \\
Betina & 1,77 \\
\hline
\end{tabular}

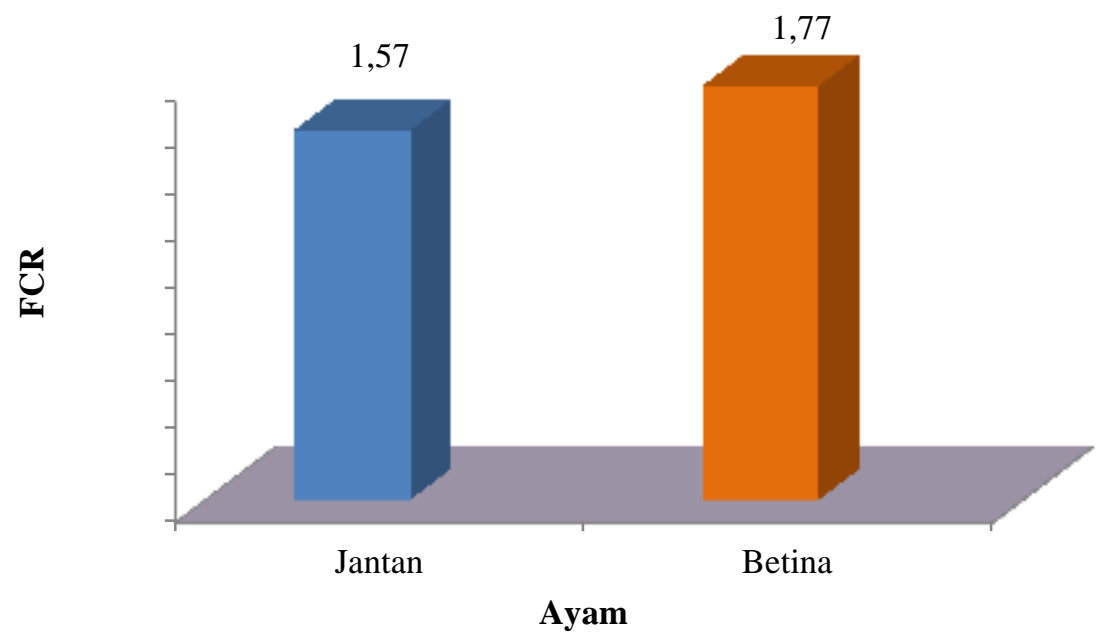

Gambar 3. Besarnya nilai konversi pakan ayam ras pedaging jantan dan betina

Hasil analisis t-test menunjukkan bahwa perlakuan sexing ayam ras pedaging berpengaruh nyata $(p<0,05)$ terhadap konversi pakan. Adanya pengaruh ini terlihat adanya perbedaan konversi pakan antara ayam ras pedaging jantan dan betina. Konversi pakan ayam ras pedaging jantan yaitu 1,57 lebih rendah dibandingkan dengan ayam ras pedaging betina yaitu 1,77. Adanya 
perbedaan yang signifikan ini lebih disebabkan oleh ayan ras pedaging jantan lebih efektif dalam mengkonversi pakan menjadi daging. Hal ini sejalan dengan pendapat North dan Bell (1990), yang menyatakan ayam ras pedaging jantan dengan bobot badan $1,66 \mathrm{~kg}$ membutuhkan pakan sekitar $2,94 \mathrm{~kg}$, sedangkan untuk ayam ras pedaging betina dengan bobot badan yang sama membutuhkan 3,26 kg. Hal ini sejalan juga dengan Kartasujana dan Suprijatna (2006), konversi pakan ayam ras pedaging jantan di usia 28 hari 1,70 sedangkan betina 1,78. Menurut hasil penelitian Triyanto (2006), suhu lingkungan berpengaruh terhadap konversi pakan, suhu $\pm 27,92^{\circ} \mathrm{C}$ konversi pakan ayam ras pedaging 1,42 .

\section{KESIMPULAN}

Perlakuan sexing memiliki pengaruh signifikan terhadap $\mathrm{PBBH}$ dan konversi pakan (FCR) namun tidak memiliki pengaruh terhadap konsumsi pakan. Rata-rata konsumsi pakan ayam jantan adalah 128,12 gram, sedangkan konsumsi pakan ayam broiler betina yaitu 120,00 gram. Pertambahan bobot badan harian $(\mathrm{PBBH})$ ayam broiler jantan lebih tinggi dibandingkan ayam broiler betina, rata-rata $\mathrm{PBBH}$ ayam broiler jantan adalah 75,61 gram, sedangkan PBBH ayam broiler betina adalah 66,28. Konversi pakan ayam broiler jantan yaitu 1,57 lebih baik dibandingkan dengan ayam betina yaitu 1,77.

\section{DAFTAR PUSTAKA}

Alsa, A. 2004. Pendekatan Kuantitatif Kualitatif dalam Penelitian Psikologi. Pustaka Pelajar, Yogyakarta.

Ermawati, Y., R. Nurhayati, dan T. Rahmawati. 2011. Penampilan Broiler Jantan dan Betina Yang Dipelihara Pada Dua Tipe Kandang Yang Berbeda. Jurnal Penelitian BPTP Ungaran, Jawa Tengah.

Muwarni, R. 2010. Broiler Modern. CV. Widya Karya, Semarang.

National Research Council (NRC). 1994. Nutrient requirements of poultry. 9th ed. National Academy ress, Washington, D.C.

North, M.O. dan D.D. Bell. 1990. Commercial Chicken Production Manual. $4^{\mathrm{TH}}$ Edition. Van Nostrand Rainhold, New York.

Triyanto, 2006. Perbandingan Performans Broiler Fase Finisher (15-28 hari) Pada Kandang Panggung dan Litter. Skripsi. Fakultas Pertanian Universitas Lampung, Lampung.

Wardhani,W.S, dan E.P.F.Setiarini. Vol 3, No. 2 Juli 2010. Menduga Pertumbuhan Bobot Ayam Broiler Strain Lohmann Dengan Pendekatan Model Logistic Dan Gompertz Brawijaya Universty, Malang. 